\title{
The Implementation of Cultivating Good Values Through Character Education in Prince's Primary School Tangerang
}

\author{
Bekti Aprilia ${ }^{1}$, Yessy Yanita Sari ${ }^{2}$, Abdul Rahman A. Ghani ${ }^{3}$ \\ Sekolah Pascasarjana Universitas Muhammadiyah Prof.DR. Uhamka, Jakarta \\ toiciiaprilia@gmail.com ${ }^{1}$ yessy.syah@uhamka.ac.id²,rahman.ghani@uhamka.ac.id ${ }^{3}$
}

\begin{abstract}
This research aims to describe how the implementation of noble values through character education at the Princes Elementary School, Tangerang. The research method used in this research is descriptive qualitative research with a case study research approach. This research was conducted on May 2020 at Princes Elementary School. Data collection using observation, interview, and document study techniques. The validity of the data used the method and source triangulation technique. Data analysis used an interactive analysis model technique consisting of: data collection, data reduction, data presentation, and conclusions. The results of research in the implementation of the values of character education are (1) The implementation of character education in the habituation activities at Princes Elementary School has been carried out by applying the values of character education, this can be seen from the behavior of students in their daily lives. Character values that stand out are leadership, never give up, tolerance, nationalism, discipline, responsibility, care for the environment, politeness. (2) The implementation of character education in extracurricular activities has implemented 5 main character values in its implementation. (3) The factors that support the implementation of character education are the idealism of the school owner, the principal who is responsible, the role of teachers who are able to be role models, the majority of parents are able to work well together. The inhibiting factor is that there are still students who do not understand right or wrong, there are still parents who do not care and the end do not support school activities. Commitment, communication, and togetherness with various parties need to be improved in the process of implementing the character values of Princes Elementary School students. A character education can be successful because there is synergy from the school, parents, and the environment. It is necessary to optimize student literacy activities in the morning, creating a conducive atmosphere so that students can participate in activities well. In implementing extracurricular activities, teachers should be more innovative.
\end{abstract}

Keywords: Implementation, Noble Values, Character Education.

\section{INTRODUCTION}

Challenge the world of education that until now still be a problem is the character of the participant students. This problem cannot be separated from the influence of globalization that has hit the world in general and in Indonesia in particular. Occurred intermingling between cultures oriental which began displaced by cultures foreign to Indonesian cultural start obscured. There is a moral crisis in every aspect of life. Sadly, this is happening to the younger generation. The influence of foreign cultures that enter without filtering will destroy the morals and morals of the nation's generation. Juvenile delinquency ranges from mild to severe. All behavior that is reprehensible that clearly pointed $\mathrm{k}$ an fragility of the characters are serious and one of the factors the cause is less the maximum development of educational character in institutions of education in schools only emphasize on 
intellectual, knowledge, skills, thus cultivation the values of character ruled out. For the sake of pursuing predicate graduation are good, many do way as any cheating mass. It 's is not directly teach the things bad to students. Characters are formed will be carried over until the child an adult. Yet when we consider more in again. All depart from the values of the characters who instilled to students. When students have good character, of course success will come to them. That's why character education is needed to shape the character of students to match the expected goals. It can make a nation to advance and prosper is to make every citizen has a character that is good. [1]

Education character is educational value, educational mind and character, education moral, educational character which aims to develop the ability of the participant students to give a decision was bad, maintain what are good and embodies goodness it in life everyday with all my heart. Education characters have a meaning that is much higher than the education of morals, for education of character is not only related to the problem correctly one, but how to instill the habit (habit) on things that good in life, so that children have the awareness, understanding, caring, and commitment to apply virtue in everyday life.

In education character as a whole needs to be emphasized in the curriculum are made to be able to explore the activity of students in seeking / eksplore material is correct. Education holistic is based on the approach of inquiry (problems solving) in which students are taught to plan, look for information / dig information, express opinions, daring in the group and mutually learn from each opinion are discussed. In addition to using the learning that is meaningful also takes creativity, a source of learning and experience of teachers in the learning thematic. By applying educational character in a holistic then expected sisawa can thrive in the physical, emotional, social, creative, religious, and knowledge is optimal. [2]. The value of the character that is applied by the Ministry of Education and Culture is covering five grades Characters Main namely religious, nationalist, independent, integrity, and mutual cooperation.

In the midst of a crisis the character of students. Prince's primary school is able to provide character education and produce students who have good enough character so that juvenile delinquency can be minimized. Based on the background behind at the top, the researchers are interested to examine more in the implementation of the cultivation the values of educational character in Prince's Elementary School Tangerang.

\section{THEORETICAL REVIEW}

Implementation is aimed at activities, actions, actions that have been systemized. Implementation is not just an activity, but is an activity that has been planned in order to achieve the objectives of the activity. [3]. Wynne in Mulyasa suggests that character means "to mark" (to mark). Someone who is lying, cheating, can be said to be a person who has a bad character, while someone who behaves well, is honest, and likes to help / give can be said to be a person who has good character. The word character comes from the Greek "charassein" which means to carve. In [4] says that forming a character is like carving a gemstone or a hard iron surface that requires patience in shaping it. Based on these definitions, it can be interpreted that character is the original / actual character that exists in a person who distinguishes himself from others. Person with character means a person with personality, behavior, character, character, or character.

The purpose of character education is to develop the potential of the heart / conscience / affective of students as humans and citizens who have national character values, develop the habits and behavior of students that are commendable and in line with universal values and religious cultural traditions of the nation, instilling a soul. leadership and responsibility of students as the nation's next generation, developing the ability of students to become independent, creative, nationalistic, developing the school life environment as a safe, honest, full of creativity and friendship, and with a high and full sense of nationality strength [4]

The 5 main character values emphasized by the ministry of education are religion, independence, nationalism, integrity, and mutual cooperation. Educational character implementation can be done by: a) Integrated in learning that awareness will be the importance of the values that are integrated in the behavior behavior of participants of learners who take place in the process of learning in the classroom; b) Integrated in self- development through extracurricular activities; c) Integrated in school management, namely those related to the management of students, school regulations, facilities and infrastructure, finance, learning and so on. [5].

The implementation of character education in schools certainly cannot be separated from the role of the teacher. In an international journal written by Aniek Irawatie et al, explained that at the college level the role of lecturers is an element of professional education that is required to have abilities and competencies with good character. Meanwhile, at the school level, the teacher plays a very important role in shaping the good character of students. Instead of forming good character for students, long before that the teacher must have good character first. Because teachers can be role models for students.

Exemplary character is the behavior or attitude of teachers and other education personel in providing examples of good actions, so that they are expected to be role models for students. If teachers and other education personnel want students to behave or behave in 
accordance with character values, then the teacher and education staff are the first and foremost people to set an example in behaving and behaving in accordance with the values adopted. In a journal written by Rabiatul Adawiah entitled "Teacher Professionalism and Character Education (Imperial Study at Balangan District Elementary School)" it was stated that the role of teachers in fostering good character of students must balance the four competencies the teacher has, namely pedagogical competence, professional competence, social competence and personality competence, the four competencies must be carried out in harmony and balance so that the results achieved are maximized.

\section{RESEARCH METHOD}

This research used qualitative method with case study approach. The case study is a study that deeply about the individual one group, one organization, one program of activities, and so on within the time specified. The results of case study research can provide a broad and in- depth picture of a particular social unit [6]. This research was conducted at Prince's Elementary School, which is located at Jln Benteng Jaya No 69, Tangerang. The subject of research in the study of this is the head master of Prince's school, teachers, extracurricular teacher, the parents of students.

Data collection techniques in this study used observation, interviews, and document study (notes or archives). In qualitative research methods, the researcher is the main instrument (key instrument). That is, this research states that the researcher himself becomes the main instrument that goes into the field and tries to gather information. [7]

\subsection{Observation}

Observations carried out by using the senses of sight and the sense of supporting the other to look at it directly phenomena or objects that were we careful. Observations in the study not only just observe and see, but done in a comprehensive, detailed, with objectives that clearly [8]. Researchers entering setting or atmosphere particular with the purpose to conduct observation is direct about how the implementation of the cultivation the values of characters on the activities of habituation in school/culture school and extracurricular Prince's Elementary School.

\subsection{Interview}

In- depth interviews in this study are one of the main techniques in collecting data for research purposes. Through interviews, investigators tried to obtain information in a direct and face to face with the respondent. interviee conduct interviews open with engineering interviews freely, without the use of guidance interviews are detailed.

\subsection{Document Study}

The documents are related to the research such as Documents curriculum level units of study (SBC) SD Princes, the plan of work yearly, document program teaching extracurricular, document assessment activities extracurricular, document assessment activities of cultivation of the values of characters, photographs of activities extracurricular, and photos of habituation activities at school.

\subsection{Data Analysis Techniques}

Data were obtained from observations, interviews, as well as the study of the document and then analyzed by using analysis of data qualitative using a model of Miles and Huberman. Activities in data analysis, namely, reduction, display, and conclusion drawing / verification. Illustrations are can be seen in the model analysis of interactive that proposed by Miles and Huberman, in figure 1

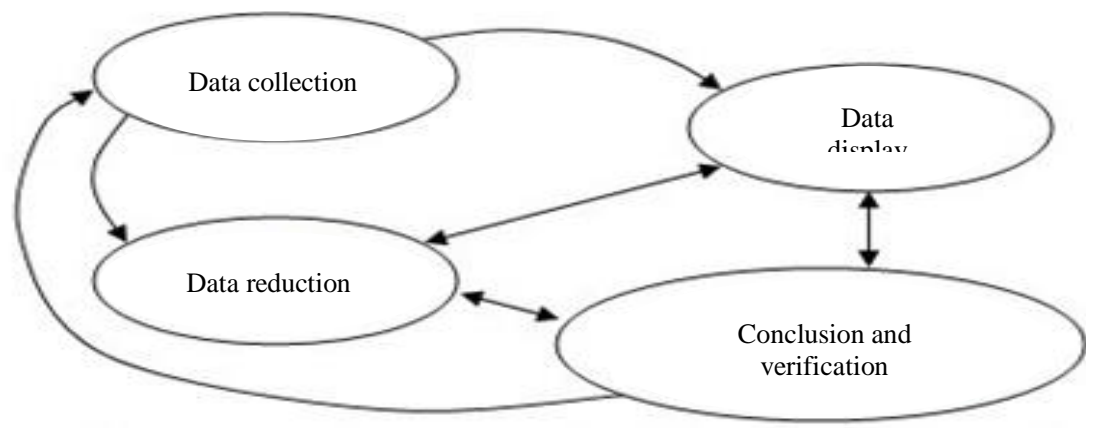

FIGURE 1 Miles and Huberman Interactive analysis modle 


\section{RESULTS AND DISCUSSION}

Education characters are applied in the Prince's Primary School according from the vision, mission, and objectives of the school are. Departing from the vision and mission that, schools develop educational character. Education characters in Prince's Primary School has been done since the school was there. The founder of the school has the idealism that high on education, how to form a personality that is good for the child so that the child can thrive with good. Three visions base which is delivered by the founder who later developed by the head of the school is as follows:

1. School -spirited National insightful International.

2. A school with the concept of multiskills, multireligions, and multiculturalism.

3. The concept of creativity is ordinary Becomes extraordinary (creativity to change something that ordinary into things that beyond the usual)

In making a vision and mission, of course, it involves many parties. Involvement in active of all stakeholder interests is one of the key successes in planning to realize the vision and mission of the school. The involvement must be done at the beginning since the formulation of a character education program that is integrated into the school program. Education characters are applied in schools Princes not only through learning alone, but integrated into the all aspects.

\subsection{Implementation of A Good Value of Education Character On Activities Habituation.}

The habituation activities at Princes Elementary School are divided into several groups. Among other things, routine habituation, such as the flag ceremony, class picket, washing hands before eating. Event spontaneous as instill a culture queued (case is often the case at the time of the students wash hands and wait turning to eat lunch), say hello like a good morning, good afternoon, to say thank you very, sorry, and excuse me, and dispose of garbage in its place. Event exemplary as fostering discipline, instill a culture read (done every morning before the entrance to the classroom), fostering orderly in the dressing school. Activity achievement of students as race student achievement, race creativity and MIPA, and the race PORSENI. The activities programmed namely performing arts (assembly), the work of travel within or outside the country (field trip or study tour), holiday camp, and graduation evening. Schools have a role that is great in developing educational character through the development of the civilizing school culture and habituation.

TABLE 1. Characters Value at habituation

\begin{tabular}{|l|l|l|}
\hline \multicolumn{1}{|c|}{ No } & \multicolumn{1}{|c|}{$\begin{array}{c}\text { Character } \\
\text { value }\end{array}$} & \multicolumn{1}{c|}{ Daily activities } \\
\hline 1. & Religious & $\begin{array}{l}\text { habitual prayer activities before and after learning activities, lunch together, and reflection } \\
\text { activities at the end of each lesson. }\end{array}$ \\
\hline 2. & Nastonalism & $\begin{array}{l}\text { The habituation activity is carrying out a flag ceremony on Monday or national holidays, } \\
\text { singing the Indonesia Raya song at the beginning of the learning activity, and singing the } \\
\text { national / regional song at the end of the lesson }\end{array}$ \\
\hline 3. & Independent & $\begin{array}{l}\text { Habitual activities in the activity of having lunch together, learning activities in completing } \\
\text { assignments, and other individual skills in everyday life. }\end{array}$ \\
\hline 4. & Cooperative & $\begin{array}{l}\text { Habitual activities in cleaning the classroom (picket) and the school environment (community } \\
\text { service), and group learning activities. }\end{array}$ \\
\hline 5. & Integrity & $\begin{array}{l}\text { The habituation activity of coming to school on time, discipline, courtesy ( the 4 magic words } \\
: \text { Sorry, Please, Thank you, and Excuse me ), behave honestly, and be responsible. }\end{array}$ \\
\hline
\end{tabular}

Value education character through activities habituation were conducted by the Prince's school are leadership, cooperation, abstinence surrender, sportsmanship, discipline, responsibility, love to read, tolerance, a sense of want to know, care, mutual respect, religious, honest, disciplined, work hard, creative, independent, democratic, the spirit of nationalism, love of the land of water, appreciate the achievements, friend, love peace, care about the environment, concerned social. Activity habituation were performed in Prince's school already includes the values of the character based on the study of the Ministry of National Education Year 2010 concerning the values of the characters that are implemented in the school.

Habituation were performed Princes Primary Schools looked at the behavior of students in accustom themselves to follow all the activities that exist in the school. Habituation were performed ranging from students enter the gates of the school until the student's home school and continued when the students at home. This is routinely 
done everyday. The activities of habituation is in line with the opinion [9] that in the conduct of habituation must be done in a routine so that habituation that becomes habit. It is reinforced by the opinion [10] that habituation is something that is purposely done by repeatedly that something that can become a habit. Habituation actual core of the experience, the habit of doing it is something that is practiced. Habituation put humans as something that is special, that can save power, because it will become a habit that is attached to, and spontaneous, so that the power it can be used for a variety of activities in each job, and the activity of the other. It is to be understood in establishing the character of the students can be created through exercise and habituation. When a case has been accustomed to do with refraction it will be a habit for who did it, then become hooked, and eventually will become a tradition that is difficult to be abandoned. It is visible on the activities of habituation which do Prince's school. When students come to school, the students immediately sit in under cover and read a book. It 's already become a habit in school are. When doing activities that are not directly the students have learned the values of educational character. Although in practice there are still some students who are not disciplined in reading books, especially low- grade students, they are grades 1 and 2 .

Discipline is one of the factors in building student character that must be nurtured from an early age. Schools should teach the value of discipline to students from an early age. It is applicable on Prince's school, discipline became a major for the school defines that "discipline like a breathing" which contains the meaning of that discipline should always be embedded in the hearts of like breathing. In line with the opinion [11] that the discipline of moral will bring students toward the behaviors that full responsibility responsibility. When a person has applied discipline in his daily life it will create an order of life.

Grade 1 and grade 2 students are still relatively new in following school habituation activities. Instilling character values in children is not easy, it takes a process to arrive at the expected goals. Siregar said that in the formation of character requires three things are sustained, continued and thorough. It is reflected in all the activities which do Princes Primary School always comes down to the character of the students, so that the vision of the mission and the purpose of which is expected to be achieved. Activity habituation good that the routine, spontaneous, preprogrammed, and are exemplary do it consistently.

In the activities of reading in the early days, the teacher appears often remind students to read the book. The teacher's role is very large in shaping the character of students in school. The role of a teacher is not only to teach, but also to educate the child, so the child not only has the intelligence, but also has a good character.
Teachers in schools not only teach (transfer of knowledge) but also educate (transfer of attitude) so that with such teachers should provide guidance on the values of the positive that prevail in the life.

Things that were done by Princes primary teachers in instilling the values of the character of the students. The teacher also provides an example to students. This is shown when students come to school, students are welcomed by the teacher and greet students who come, the teacher also shows discipline by coming on time as well as students. The teacher's example is very important because every teacher's movements can't be separated from the students' view. With the example of which is shown by the teacher are automatically make students follow. In line with the opinion of Rina Palunga and Marzuki that the example that indicated teachers in schools that teachers not only talk but also do the deed, as one example is better than a thousand counsel. [12]

In accordance with the opinion [11] that in teaching educational character on the student must involve three things, namely knowledge morals, feelings of moral, and act morally. What are the views of students of a teacher both the behavior and the nature of the teacher becomes knowledge moral for students, the students then analyze the behavior of the teachers that in mind, and at the end students show actions moral. By because it is how the importance of exemplary teacher for students. Teachers should be careful in acting as well as in words.

Giving rewards and punishments can also be a tool for character education to be successful. Giving the reward will be a motivation for students to continue to develop the character of the good. Princes Primary School give awards to students in the form of honour certificate, awards were given to students who experienced an increase them character. In addition, awards are also given to the best students in their class. Assessment is in the form of assessment of academic and assessment attitude. By giving awards to students can lead to the motivation of students to be able to be good, because the essentially human in need of awards in her life. Giving the award to the child would increase the behavior that is in accordance with the rules that apply, as well as making the child to avoid themselves from actions that are not in accordance with the rules. By giving the award the child will attempt to behave discipline.

Punishment is also needed in developing character education, punishment can be a trigger for someone not to repeat the same mistakes. System punishment were carried out in Princes Primary school adjusted to the level of the level. The punishment is based on the level of error. It is in accordance with the opinion Supriya, Kiftiah, \& Agusnadi, which states that the punishment always contains the taste is not palatable to the child, by because it is in the giving punishment of education should consider the punishment that will be given in accordance with the error that is done. Punishment as an action that 
was dropped to the children are consciously and deliberately so that the cause sorrow. With the agony of children will be aware of will his actions and promised in the heart to not repeat it. Penalties are given if a reprimand and a warning has not been able to prevent children in conduct violations. In accordance with the opinion [13] that in awarding the penalty based on the stage.

\subsection{Implementation of the value of Education Character On Activity Extracurricular}

Prince's Primary School has 1 compulsory extracurricular namely scouts, and 16 extracurricular choices, namely painting, dance, drumband, badminton, vocational training, handicrafts, science and math clubs, liong, futsal, theater, music ensemble, philately, saman dance club, cisadane dance club, wushu, and table tennis. Based on the results of observations which do researchers for researchers to teach in elementary Princes, the implementation of the extracurricular is common in Prince's Primary School, are as follows:

1. After the bell incoming class hours of extracurricular reads, children moving into extracurricular respectively. It was still seen that some children did not immediately go to the extracurricular activities

2. Points for extracurricular namely: field greens for extracurricular dragon, a field of red for the marching band, space art $\mathrm{n}$ craft for extra craft hand, chamber hall for theater, chamber dance for extracurricular dance.

3. For some extracurricular activities, there are children who are less disciplined. For example, late heading to the place of extracurricular.

4. Teachers picket doing the traverse in each room to make sure whether all students had to be in the place of extracurricular.

5. Before starting extracurricular activities, teachers guide students to pray.

6. During extracurricular activities, the supervising teacher and the trainer train students by providing material and developing character education values in each of their activities. Examples of the extracurricular liong, seemed student lead in doing warming. It is certainly develop the value of the character believes himself and leadership. When the activity takes place, the liong extracurricular activity requires cooperation between students, because the liong is played by 9 students, this can also train students to respect each other. In addition, in theater activities, students appear to take turns appreciating the poetry they have written. It is trained sense believe themselves to show the results of his creation. Extracurricular art of dance, Saman dance, and dance Cisadane club in addition to train believers themselves also train a sense of love ground water, because students learn about cultures that exist in Indonesia, students more familiar culture of the country itself - Extracurricular ensembles or art music also teaches students to more trust yourself, self, discipline, and held responsible and nationalist. Each activity extracurricular were done to foster the values of the character of the students. In addition to the student can channel the talents and interests, students are also able to develop the values of characters are obtained. It can be seen that there are still some children who are less disciplined, the teacher gives a warning, if the warning is ineffective, the teacher gives punishment by giving time out to students in doing activities.

7. To end the activity, students pray together before returning to their respective classes.

The aim their extracurricular activities in Prince's school is a container for the participant students to develop potential talents and interests. Students choose extracurricular based talent that is owned and interest. The teacher guides students in choosing extracurricular activities. Interest extracurricular in Schools Princes in accordance with the description Permendikbud No. 62, Year 2014 Article 1. The existence of extracurricular is to be able to develop interests and talents of students. Students are expected to be able to optimize themselves, be able to actualize themselves, and show their abilities. With their extra-curricular will provide benefits for the students are, the time to spare for students can be channeled into the things that positive, because now is a lot of children teens or age school that fall into in terms of the negative, the behavior that is deviant. By thus extracurricular greatly assist students in actualize themselves. Each child coined the potential that is different, the potential of the child that should be channeled to the direction of the right. What were conducted by the School Princes has been in accordance with the opinion [14] that the potential is the ability of basic human that can be fostered through education.

By thus potential who owned the child is different, then with having one 17 activity development of self (extracurricular) is appropriate. Students can have many choices according to their interests. In the activity development of self is certainly should pay attention to the development of character in students, because of the development of self is one of the processes that can be used to achieve perfection or maturity of life, in the development of self- individuals can develop the talent that is possessed, realize dreams, increase the sense of trust themselves, be strong in the face of trials, and have a good relationship with each other. Self- development in 
extracurricular activities is directed at developing student character. Students are able to develop themselves in accordance with their potential and have a character that is good of course will bring success to the students of the future. The activity in extracurricular who organized the school is one of the media that the potential for the development of character. The existence of extracurricular activities supports the development of student character. The character of students begins to be trained and directed with the guidance of the teacher. The findings of the focus of research is also reinforced in a journal that is entitled " Implementation of Educational Character Through Extracurricular Pencak Silat Tapak Suci Putra Muhammadiyah In Sd Muhammmadiyah 1 Menganti Gresik" which states that the development of the character can be performed on activities extracurricular. [15]

Implementation extracurricular activities were conducted in the Prince's Primary School have developed the values of characters such as discipline, responsibility responsible, polite manners, caring environment, cooperation, creative, believe in yourself, religious, mutual respect, tolerance, love of the land of water, patience, self-reliance, grace sense, care, patience, tolerance, perseverance, a sense of want to know that high, spirit, mutual cooperation. It is also in accordance with the opinion of the journal are titled " Planting Values Education Character Students Through Event Extracullicar Scout " which convey that the planting of 18 grades of character can be performed on activities extracurricular. [16]

The development of character values in extracurricular activities can be seen in student activities. When the extracurricular clock bell rings. Students are independently heading to where the activities extracurricular underway. It's is not directly teach aspects of discipline, self-reliance, and responsibility. Students who directly towards the place with the right time would already show three characters at the top. Discipline for someone is a thing that is very important, a child in need of discipline in his life so that life becomes organized and purposeful. To form the discipline of children in need of guidance and direction of the adults. It is in accordance with the theory that delivered by [17] in which the discipline that full guidance will assist children in doing actions were correct.

Discipline character is also shown in participating in extracurricular activities from start to finish in an orderly manner. Discipline that is applied in each activity extracurricular that give effect to the growth of personality that well. By because it is, to discipline someone will be used to follow, abide by the rules that apply and habits of the old gradually entered into within himself as well as play a role in building a personality that is good. For students who are less disciplined will be given sanctions, sanctions can be in the form of reprimands or time out from extracurricular activities.

Religious characters seem when students perform prayers together before and after the follow activities. In accordance with the understanding of the character of the religious were submitted by the Ministry of National Education Year 2010. Religious is the attitude and behavior were obedient in carrying out the teachings of the religion espoused, tolerant towards the implementation of the practice of other religions and live in harmony with the followers of other religions. Religious culture of students who differ cultivate an attitude of tolerance among fellow students. The attitude of the religious need to be developed in the life of everyday, which in it contains the values of educational character. In this religious attitude, it is emphasized that they live in harmony with adherents of other religions. It is very visible once in Prince's Primary School, because they are derived from religion and culture are different but still get along well. For example, only when the activity of extracurricular which took place on the day Friday. There are some students who are Muslim late in joining extracurricular activities because they are praying and other students understand it. The attitude of mutual respect looks at the behavior of students everyday.

Nationalist characters also appear in extracurricular activities at Princes Primary School. In certain extracurricular activities, they learn about the culture of our own country. Examples dances area, songs area, art area. The characteristic of nationalist character is having a sense of pride and affection towards the identity of the nation which grows, one of which is culture. Those who have the value of character nationalist whose height will have the pride of the height of the culture of the nation and contribute actively to preserve it. The growth of nationalist character values can be built through multicultural education.

Multicultural education, as quoted by Mahfud, is an education about cultural diversity. [18] activities extracurricular that exist in the Prince's Primary School have to enter the values of the culture of the nation Indonesia so that the value of nationalist students can be formed. Of the overall description of the values of the characters that have been implemented in Prince's school on activities of extracurricular already in accordance with the assessment of the Ministry of National Education Year 2010 the value of the character that is implemented in the school. Extracurricular activities are one of the areas in developing students' character values. When students happy doing activities, especially activities extracurricular which has become a choice, then it will be easier the students are in absorbing the knowledge that is given. 


\subsection{Supporting and Inhibiting of the value of Education Character factors}

\subsubsection{Supporting Factors}

Teachers have a role that is very important in the formation of the character of the students. In Prince's Elementary School, the teacher becomes a role model for students in instilling character values. Teachers tried tobe the maximum to be able to be an exemplary student, ranging from discipline, responsibility, cooperation, caring environment, nationalism, and so on which is shown every time. By seeing the attitude of the teacher can be the motivation of students to imitate the attitude of the teacher mentioned. In addition to be a role model, a teacher at the school Princes also constantly monitoring and guiding the students, reminding the students. In cultivating the education of character is not easy by because the teachers in elementary Princes school also did approach is personal to the students. This is to foster trust in teachers and student honesty. Teachers always assist students in activities.

The collaboration shown by the teacher can also be an example for students. The role of teachers do in Prince's school in line with the statement Ki Hajar Dewantara in his book has been emphasizing on the importance of exemplary [19]. One of the philosophies is ing ngarso sung tuladha, which means that an educator should be able to give an example that both the participants of their students.

It similar also presented in the journal which was written by Rabiatul Adawiah that the role of teachers in a growing character of both students must balance the four competencies are owned by teachers, namely competence pedagogic, professional, social, and competence of the personality, the four competencies that must be done in harmony and balanced so that the results are achieved also the maximum.[20] . It is reinforced by the opinion Zairin that teachers must understand the learner according emotions, actions and behaviors they are and are slowly doing the changes are necessary. [21]

Schools culture that exist in the Prince's Primary School became one of the factors supporting the successful implementation of educational character in Prince's Primary School. Disclosed that in the Prince's school has been implementing educational character since schools are established, habituation-conditioning either do it continuously so that became the culture of the school. As culture queued, culture reading, mutual help helpfulness, caring environment, and others. The culture of the school that has been arranged neatly and both will greatly assist students in forming his character. Means infrastructure are adequate also be a factor supporting the success of educational character in Prince's Primary School. Schools facilitate students in carrying out their activities. Neither the activities of extracurricular and activities of others.

The majority of students in the Prince's School could be said as the children were obedient. This student obedience makes it easier to implement the value of character education for students. Since the beginning, students are always taught what is right and what is not right, what is good and what is not good. By constantly being students are taught by teachers who must work together with all parties.

The student's sense of responsibility and enthusiasm in carrying out each activity, as well as student's awareness of the importance of character education have also been embedded in the minds of students. The formation of the character of the students would not be separated from the role of the parents at home who also form the character of the students. Environment in which the student was developing. Attitudes of parents towards their children, father to mother, or parents to neighbors. This behavior has a significant effect on the child. The social progress of children depends on the family, which is none other than the starting location from which to be socialized by action. In line with the opinion [11] that the family is a source of education moral of the most prime for children. It is reinforced by [22] that the development of children starts from the education that is given in the family, the family, especially the parents really held the role that important.

In maintaining relations both with the parents, Prince's Primary School often conduct activities that involve the parents, holding seminars parenting. So that anything that becomes the destination school for children also can be understood by the parents so that the established cooperation that both between the parents and the school. The majority of the parents to support any activities that are held at the school. Habits at school have also been applied at home by the majority of parents, so they don't just drop out at school. It is agreed with [23] that the parents can be in line with the school in developing the character of children through a variety of ways, one of them by using application -based characters that have been developed by experts.

\subsubsection{Inhibiting Factor}

Factors inhibiting the application of the values of educational character in Prince's Elementary school mutually related. For example only, still there are students who have not knowwhere things are right and where things went wrong. Surely this is not just a factor of the students, but the factor of the elderly at home in educating children. What is the role of the parents, how deep the parents have taught their children at home will be seen in the behavior of students at school. Most of the parents of students at Prince's Elementary School are workers. It is certainly brings impact/influence on the 
development of the child. The busyness of parents, especially mothers at work, greatly affects student development. This is very visible in the attitudes of students when they are at school. Still there are students who have not demonstrated an attitude of discipline and responsibility in charge.

Some of the parents still think that in shaping the behavior of the students enough in the school alone, so the parents off the hands and surrender completely to the school. Of course this becomes obstacle great for schools to realize the character of the students are good. Due to the formation of student character there must be collaboration between the school and parents. During 're at school, children are the sole responsibility of the school and when being at home, of course the parents who are responsible. Time children in school only 8 hours, the rest is the time at home. Of course, the role of parents is very influencing.

Schools already facilitate the elderly to interact with the school. But sometimes the parents are still ignorant. For example, when the school held activities parenting, not all of the parents present. This is an obstacle, important information should be conveyed but not conveyed. Although still there are some problems the school continues to strive to overcome the constraints mentioned. Based on the results of interviews with stakeholder in the school and the parents that can be said that so far this implementation of character education in Prince's Primary School has brought the impact that significant to the behavior of students.

\section{CONCLUSION}

Implementation of the value of character through habituation activities in Prince's Primary School done by holding various activities to familiarize the students carry out the values of the character of both activity routine daily, activity ideals, activities spontaneously, and the activities of Fixed. Various activities are made in such a way that character values can be embedded in the minds of students, in accordance with the vision and mission of the school. The character values that stand out are the values of leadership, never giving up, self- confidence, toughness, tolerance, respect for others, caring for the environment, and discipline. In practice, the teacher has a role that is very important. The teacher as a role model for students. character education through habituation give the impact that positive for the development of the character of the students. Most of Prince's Elementary School students have shown behaviors that develop the noble values of national character.

The development of character through activities extracurricular very effective to do. Through 17 events extracurricular that exist in the Prince's Primary School been giving contribution to the positive in developing the values of character. The characters value that stand out are taught in activities extracurricular is value creative, discipline, responsibility responsibility, trust yourself, cooperation, nationalism, religious, leadership, tolerance. Factors supporting the successful cultivation of the values of characters in Prince's Primary School is idealism owner of the school and the stakeholders of the school, the cooperation of the school and the parents, the role of teachers optimally in instilling the values of educational character, facilities and infrastructure are adequate, and most large students who have awareness and compliance with school regulations. While the inhibiting factor for the implementation of character education at Prince's Elementary School is that there are still students who do not care about the activities or the importance of character values. This is due to student's ignorance of which things were right and which things were wrong. Besides that, still there are some people older are less participate in various activities at the school, the parents are still there are less caring and just handed educational character of the child to school alone. Even though there are still some obstacles, the cultivation of character education in Prince's Elementary School is said to have been successful because its implementation has included five main character values. The success of these also can be seen from the behavior of students in the School, the feedback from the parents.

Recommendations of the results of research it is each party can maximize its role in developing the values of the character of the child, either the teachers in giving an example, the attitude of cooperative the parents with the school so that the implementation of the education code is not limited only performed at the school but also applied at home. Teachers supervising extracurricular more innovative by holding various activities in instilling the values of the characters so that the development of the values of characters in extracurricular get the results of the maximum.

\section{REFERENCES}

[1] Megawangi R., Pendidikan Karakter (edisi revisi), (Indonesia Heritage Foundation, Depok, 2016).

[2] Syarif, S., A. Ghani, A. R., \& Suyatno, The Model of Implementing Character-based Holistic Education in Learning. International Journal of Economic Research, 14(12), 1-10, (2017)

[3] Usman, N., Konteks Implementasi Berbasis Kurikulum, (CV Sinar Baru, Bandung, 2002)

[4] Judiani S., Implementasi Pendidikan Karakter di Sekolah Dasar Melalui Penguatan Pelaksanaan Kurikulum. Jurnal Pendidikan dan Kebudayaan 16 (9), pp 280-292 (2015)

[5] Wibowo, A., Manajemen Pendidikan Karakter di Sekolah, (Pustaka Pelajar, Yogyakarta, 2016) 
[6] Gunawan I, Metode Penelitian Kualitatif Teori dan Praktik (3rd ed.), (Bumi Aksara, Jakarta, 2015)

[7] Moleong, L. J., Metodologi Penelitian Kualitatif (36th ed.), (PT Remaja Rosdakarya, Bandung, 2017)

[8] Ghani, A. R. A, Metodologi Penelitian Tindakan Sekolah, (Rajawali Press, Jakarta, 2014)

[9] Azizy. Q, Pendidikan Agama untuk Membangun Etika Sosial (Aneka Ilmu, Semarang, 2002) Chairunnissa. C, Metode Penelitian Ilmiah Aplikasi Dalam Pendidikan Dan Sosial, (Mitra Wacana Media, Jakarta, 2017)

[10] Mulyasa, E., Manajemen Pendidikan Karakter, (Bumi Aksara, Jakarta, 2018)

[11] Lickona. T, Educating For Character : Mendidik untuk Membentuk Karakter (5th ed.). (Bumi Aksara, Jakarta, 2016).

[12] Palunga, R., \& Marzuki., Peran Guru Dalam Pengembangan Karakter Peserta Didik Di Sekolah Menengah Pertama Negeri 2 Depok Sleman. Jurnal Pendidikan Karakter, VII(1), 109123, (2017).

[13] Sholeh, A., Endah, D., \& Adhi, Bentuk Ketegasan Dalam Proses Pembelajaran "Dampak Sanksi Terhadap Kedisiplinan Siswa Di Sdn Kaliwiru Semarang. Journal of Primary and Children's Education, 2(2), 120-134, (2019)

[14] Muhaimin, \& Mujid, A., Pemikiran Pendidikan Islam; Kajian Filosofis dan Kerangka Dasar Operasionalisasinya, (Trigenda Karya, Bandung,
1993)

[15] Muis, A., Implementasi Pendidikan Karakter Melalui Ekstrakurikuler Pencak Silat Tapak Suci Putra Muhammadiyah Di Sd Muhammmadiyah 1 Menganti Gresik. Jurnal Penelitian Pendidikan Guru Sekolah Dasar, 6(12) (2018)

[16] Elisa, Adhi, S., \& Hadi, H. Penanaman Nilai-Nilai Pendidikan Karakter Siswa Melalui Kegiatan Ekstrakulikuler Pramuka. Mimbar PGSD Undiksha, 7(2), 176-186. (2019)

[17] Gunarsa, Y. S., Psikologi Perkembangan Anak dan Remaja, (BPK Gunung Mulia, Jakarta, 2006)

[18] Mahfud C., Pendidikan Multikultural, (Pustaka Pelajar, Yogyakarta, 2006)

[19] Tohir, M., Sosok Guru Profesional yang Ideal Ala Ki Hajar Dewantara. (2016).

[20] Robiatul, A., Profesionalitas Guru Dan Pendidikan Karakter (Kajian Emperis Di Sdn Kabupaten Balangan). Jurnal Pendidikan Kewarganegaraan, 6(11), 939-946, (2016)

[21] Zairin, Peran guru Dalam Pengembangan Karakter Pembelajar. Jurnal Georafflesia, 3(1), 1-11, (2018)

[22] Siregar, D., \& Sari, Y, Membidik Karakter Hebat, (Gema Insani, Jakarta, 2017).

[23] Sari, Y. Y., Zulaiha, S., \& Mulyono, H., The development of a digital application to promote parents' involvement in a character education at primary schools. Paper in Review, 19(04), 25642570, (2019) 